\title{
Faktor-Faktor yang Berhubungan dengan Kemampuan Sosialisasi Anak
}

\author{
Nurul Komariah, ${ }^{*}$ Farid, ${ }^{* *}$ Sjarif Hidayat Effendi ${ }^{* *}$ \\ *Poltekkes Kemenkes Palembang Jurusan Kebidanan \\ ** Departemen Epidemiologi dan Biostatistika Fakultas Kedokteran Universitas Padjadjaran \\ ${ }^{* * *}$ Departemen Ilmu Kesehatan Anak RSUP Hasan Sadikin Fakultas Kedokteran Universitas Padjadjaran, Bandung
}

Latar belakang. Kemampuan sosialisasi berkontribusi besar bagi kesiapan anak bersekolah dan keberhasilan akademik. Banyak faktor yang berhubungan dengan kemampuan sosialisasi anak antara lain pendidikan ibu, pekerjaan ibu, status ekonomi dan pola asuh. Tujuan. Mengetahui hubungan pendidikan ibu, pekerjaan ibu, status ekonomi, pola asuh dengan kemampuan sosialisasi anak. Metode. Penelitian menggunakan metode cross sectional. Subjek penelitian adalah anak-anak yang mengikuti PAUD Kecamatan Seberang Ulu I Palembang tahun 2013 yang memenuhi kriteria inklusi. Dilakukan analisis untuk mengidentifikasi hubungan pendidikan ibu, pekerjaan ibu, status ekonomi, pola asuh terhadap kemampuan sosialisasi anak. Pola asuh dinilai menggunakan parenting style questionaire (PSQ), sedangkan kemampuan sosialisasi anak dengan interaction rating scale (IRS).

Hasil. Empatpuluh anak diikutkan dalam penelitian. Pola asuh non otoritatif merupakan satu-satunya faktor yang ditemukan secara bermakna berhubungan dengan kurangnya kemampuan sosialisasi anak setelah analisis multivariat ( $\mathrm{p}=0,001 ; \mathrm{OR} 52,80$ ).

Kesimpulan. Pola asuh non otoritatif berhubungan dengan kekurangan kemampuan sosialisasi anak. Sari Pediatri 2017;18(5):373-8

Kata Kunci: pola asuh, kemampuan sosialisasi

\section{Factors Associated with Social Skills in Children}

Nurul Komariah, ${ }^{*}$ Farid, ${ }^{* *}$ Sjarif Hidayat Effendi ${ }^{* *}$

Background. Social skillscontribute highly toschool readiness andacademic success of a child. Various factors are associated with a child's social skills, such as mother's educational level and occupation, economic status and parenting style.

Objective. To identify the association between mother's educational level, occupation, economic status, parenting style and children's social skills.

Methods. This study was a cross sectional study on children attending Seberang Ulu I district of Palembang kindergarten. Analysis was performed to identify association between mother's education,mother's occupation, economic status, parenting style and social skills of the children. Parenting style was evaluated using Parenting Style Questionnaire (PSQ), while social skills were evaluated withInterraction Rating Scale (IRS).

Results. Forty children were included in the study. Non authoritative parenting style is the single factor found to be associated with lower social skills in children after multivariate analysis ( $\mathrm{p}=0.001$; OR 52.80 with 95\% CI 5.51-505.64).

Conclusion. Non authoritative parenting style is associated with lower social skills in children. Sari Pediatri 2017;18(5):373-8

Keywords: parenting style, social skills

Alamat korespondensi: Nurul Komariah, SST, M.Keb. Poltekkes Kemenkes Palembang Jurusan Kebidanan Jln. Sudirman Km 3,5 Palembang. Email: nurulkomariah46@ymail.com. 
Nurul Komariah dkk: Faktor-faktor yang berhubungan dengan kemampuan sosialisasi anak

U sia 0-5 tahun merupakan masa emas perkembangan anak, dan terjadi lonjakan luar biasa yang tidak terjadi pada periode berikutnya. Para ahli menyebutnya sebagai usia emas perkembangan (golden age). ${ }^{1}$ Penelitian terdahulu untuk perkembangan selanjutnya lebih terfokus pada perkembangan awal kognitif anak. Walaupun demikian, domain non kognitif juga dapat memprediksi hasil karya anak, produktivitas, dan fungsi sosial pada saat dewasa. ${ }^{2}$

Kemampuan sosialisasi berkontribusi besar terhadap kesiapan anak bersekolah dan keberhasilan akademik. ${ }^{3}$ Anak berkemampuan sosialisasi rendah sering mengalami kemunduran prestasi akademik dan banyak yang tidak naik kelas. Anak dengan prestasi akademik yang rendah selama sekolah dasar berisiko lebih tinggi untuk memiliki perilaku antisosial dan drop out di sekolah menengah atas. ${ }^{4}$ Keluarga berperan sebagai kerangka sosial pertama tempat manusia berkembang sebagai mahluk sosial. ${ }^{6}$ Keluarga adalah faktor terpenting yang berpengaruh dalam perkembangan kemampuan sosialisasi anak. ${ }^{7}$ Agen sosialisasi dalam sistem keluarga berperan besar pada tahap awal karena anak sepenuhnya berada dalam lingkungan keluarganya terutama orang tua. ${ }^{6,8,9}$

Faktor-faktor dari orang tua yang diketahui berkaitan dengan kemampuan sosialisasi anak, yaitu pendidikan dan pekerjaan orang tua, serta status ekonomi. ${ }^{10}$ Ibu merupakan orang yang paling berperan dalam kemampuan sosialisasi anak, tetapi semua orang tua mengetahui perannya dalam kemampuan sosialisasi anak. Tujuan penelitian untuk menganalisis hubungan antara faktor pendidikan ibu, pekerjaan ibu, status ekonomi, pola asuh dengan kemampuan sosialisasi anak.

\section{Metode}

Penelitian studi analitik dengan desain cross sectional yang dilakukan pada bulan September-November 2013 di Kecamatan Seberang Ulu I Kota Palembang. Subjek penelitian ini adalah seluruh anak yang mengikuti kegiatan di pendidikan anak usia dini (PAUD) Kecamatan Seberang Ulu I Kota Palembang tahun 2013 beserta ibunya yang memenuhi kriteria inklusi dan eksklusi. Pendidikan anak dan interaksi teman sebaya merupakan variabel yang berpengaruh bagi kemampuan sosialisasi anak. Oleh karena itu, peneliti melakukan restriksi untuk mengontrolnya dengan cara memilih anak yang mengikuti kegiatan di PAUD.

Kriteria inklusi adalah anak yang diasuh oleh orang tua, status orang tua utuh, ibu pada saat penelitian berada di PAUD, dan setuju ikut dalam penelitian setelah mendapatkan informasi dari peneliti. Kriteria eksklusi adalah anak yang diketahui terdapat riwayat sakit pada masa perinatal, adanya kelainan anatomis berat dan gangguan neuropsikiatri, serta ibu tidak bisa baca tulis. Jumlah subjek dihitung dengan cara role of thumb, maka jumlah subjek yang dibutuhkan 40 . Teknik pengambilan sampel dengan cara purposive sampling.

Kuesioner berupa biodata dan interaction rating scale (IRS) digunakan untuk menilai kemampuan sosialisasi anak. Alat ukur yang dikembangkan di Jepang dan sudah diuji validitas dan reliabilitasnya. ${ }^{7}$ Penilaian kemampuan sosialisasi anak dilakukan oleh psikolog dengan mengevaluasi hasil IRS ditambah dengan pengamatan cara anak dan ibu bermain puzzle selama 5 menit. Faktor yang dianalisis untuk pengaruhnya terhadap kemampuan sosialisasi adalah pola asuh, pendidikan ibu, pekerjaan ibu, status ekonomi. Pola asuh dinilai dengan kuesioner parenting style questionaire (PSQ) ${ }^{11}$ yang diisi ibu. Alat ukur ini terbagi atas tiga bagian, yaitu otoritatif, otoriter, dan permisif. Masing-masing bagian memiliki skor 1-6 dari "tidak pernah" sampai "selalu". Bagian otoritatif memiliki13 pertanyaan dengan total skor 13, bagian otoriter juga memiliki 13 pertanyaan denganskor 13 , sedangkan pada pola asuh permisif terdapat 4 pertanyaan. Hasil akhir skoring nilai total dibagi empat. Skor bagian tertinggi mengindikasikan tipe pola asuh. Variabel tingkat pendidikan ibu dibagi menjadi tiga, yaitu pendidikan dasar (SD-SMP), pendidikan menengah (SMA), dan pendidikan tinggi (perguruan tinggi). ${ }^{12}$ Status ekonomi dibagi menjadi dua, yaitu tinggi jika pendapatan $\geq$ upah minimum Kota Palembang tahun 2013, yaitu Rp 1.450.000,00 dan rendah jika pendapatan $<$ Rp $1.450 .000,00 .{ }^{13}$

Analisis statistik dilakukan dengan Staltat. Analisis bivariat dilakukan dengan uji chi-square untuk mengetahui hubungan masing-masing variabel bebas dengan kemampuan sosialisasi. Analisis multivariat regresi logistik dilakukan untuk menilai variabel yang paling dominan pada kemampuan sosialisasi anak. Penelitian telah mendapatkan persetujuan etik dari Komite Etik Penelitian Kesehatan Fakultas Kedokteran Universitas Padjadjaran Bandung. 
Tabel 1. Karakteristik responden

\begin{tabular}{|c|c|c|}
\hline Karakteristik & $\mathrm{n}$ & $\%$ \\
\hline \multicolumn{3}{|l|}{ Usia anak (tahun) } \\
\hline $3-4$ & 6 & 15 \\
\hline$>4-5$ & 34 & 85 \\
\hline \multicolumn{3}{|l|}{ Jenis kelamin } \\
\hline Laki-laki & 24 & 60 \\
\hline Perempuan & 16 & 40 \\
\hline \multicolumn{3}{|l|}{ Saudara } \\
\hline Tidak ada & 13 & 32,5 \\
\hline Ada & 27 & 67,5 \\
\hline \multicolumn{3}{|l|}{ Usia ibu (tahun) } \\
\hline$<20$ & 2 & 5 \\
\hline$\geq 20$ & 38 & 95 \\
\hline \multicolumn{3}{|l|}{ Pendidikan ibu } \\
\hline Dasar & 17 & 42,5 \\
\hline Menengah & 17 & 42,5 \\
\hline Tinggi & 6 & 15 \\
\hline \multicolumn{3}{|l|}{ Pekerjaan ibu } \\
\hline Tidak bekerja & 35 & 87,5 \\
\hline Bekerja & 5 & 12,5 \\
\hline \multicolumn{3}{|l|}{ Pendidikan ayah } \\
\hline Dasar & 12 & 30 \\
\hline Menengah & 22 & 55 \\
\hline Tinggi & 6 & 15 \\
\hline \multicolumn{3}{|l|}{ Pekerjaan ayah } \\
\hline Tidak bekerja & 1 & 2,5 \\
\hline Bekerja & 39 & 97,5 \\
\hline \multicolumn{3}{|l|}{ Status ekonomi } \\
\hline Rendah & 27 & 67,5 \\
\hline Tinggi & 13 & 32,5 \\
\hline
\end{tabular}

\section{Hasil}

Didapat 40 anak yang mengikuti PAUD Kecamatan Seberang Ulu I dan orang tuanya ikut dalam penelitian. Karakteristik responden tertera pada Tabel 1.

Berdasarkan Tabel 1 tertera usia responden, 85\% berusia 4-5 tahun. Ibu yang berpendidikan tinggi hanya $15 \%$ dari total subyek. Sebagian besar ibu tidak bekerja (85\%), status ekonomi rendah ditemukan pada $67,5 \%$ responden. Evaluasi terhadap kemampuan sosialisasi menunjukkan $23(57,5 \%)$ anak memiliki kemampuan sosialisasi rendah dan 17 (42,5\%) memiliki kemampuan sosialisasi tinggi. Hubungan dari beberapa faktor dengan kemampuan sosialisasi tertera pada Tabel 2.

Variabel yang ditemukan berhubungan dengan kemampuan sosialisasi, yaitu pola asuh dengan $\mathrm{p}<0,001$. Anak yang mendapatkan pola asuh non otoritatif berisiko memiliki kemampuan sosialisasi rendah 10,593 kali dibandingkan anak yang mendapat pola asuh otoritatif. Selanjutnya, dilakukan analisis regresi logistik terhadap variabel-variabel dengan $\mathrm{p}<0,25$, yaitu pekerjaan ibu, status ekonomi, dan pola asuh. Pola asuh non otoritatif merupakan faktor dominan yang berhubungan dengan terjadinya kemampuan sosialisasi rendah $(\mathrm{p}=0,001)$. Anak yang dibesarkan dengan pola asuh non otoritatif berisiko 52,8 kali memiliki kemampuan sosialisasi rendah setelah penyesuaian.

Tabel 2. Hubungan antara pendidikan dan pekerjaan ibu, status ekonomi, pola asuh dengan kemampuan sosialisasi anak

\begin{tabular}{|c|c|c|c|c|c|c|c|c|}
\hline \multirow{3}{*}{ Variabel } & \multicolumn{6}{|c|}{ Kemampuan sosialisasi } & \multirow{3}{*}{$\mathrm{X}^{2}$} & \multirow{3}{*}{$\mathrm{p}^{*}$} \\
\hline & \multicolumn{2}{|c|}{ Rendah } & \multicolumn{2}{|c|}{ Tinggi } & \multicolumn{2}{|c|}{ Total } & & \\
\hline & $\mathrm{n}$ & $\%$ & $\mathrm{n}$ & $\%$ & $\mathrm{n}$ & $\%$ & & \\
\hline \multicolumn{9}{|l|}{ Pendidikan ibu } \\
\hline Dasar & 11 & 64,7 & 6 & 35,3 & 17 & 100 & 1,807 & 0,405 \\
\hline Menengah & 10 & 58,8 & 7 & 41,2 & 17 & 100 & & \\
\hline Tinggi & 2 & 33,3 & 4 & 66,7 & 6 & 100 & & \\
\hline \multicolumn{9}{|l|}{ Pekerjaan ibu } \\
\hline Tidak bekerja & 22 & 62,9 & 13 & 37,1 & 35 & 100 & 3,288 & 0,093 \\
\hline Bekerja & 1 & 20 & 4 & 80 & 5 & 100 & & \\
\hline \multicolumn{9}{|l|}{ Status ekonomi } \\
\hline Rendah & 14 & 51,9 & 13 & 48,1 & 27 & 100 & 1,085 & 0,244 \\
\hline Tinggi & 9 & 69,2 & 4 & 30,8 & 13 & 100 & & \\
\hline \multicolumn{9}{|l|}{ Pola asuh } \\
\hline Non otoritatif (otoriter + permissif) & 22 & 81,5 & 5 & 18,5 & 27 & 100 & 19,551 & $<0,001$ \\
\hline Otoritatif & 1 & 7,7 & 12 & 92,3 & 13 & 100 & & \\
\hline
\end{tabular}

*uji chi-square 


\section{Pembahasan}

Hasil penelitian menunjukkan bahwa tidak terdapat hubungan antara pendidikan, pekerjaan ibu, dan status ekonomi dengan kemampuan sosialisasi anak. Berbeda dengan penelitian Pushpalata ${ }^{13}$ yang melaporkan bahwa kemampuan sosialisasi anak dipengaruhi oleh status ekonomi, pendidikan ibu, pekerjaan ayah dan ibu. Begitu juga penelitian Carneiro ${ }^{14}$ melaporkan bahwa pendidikan ibu dan lingkungan rumah berhubungan dengan perkembangan anak. Penelitian Gershoff $^{15}$ melaporkan bahwa pendapatan keluarga yang tidak cukup berhubungan dengan pola asuh dan perkembangan anak. Pendidikan, pekerjaan ibu dan status ekonomi tidak berhubungan langsung dengan kemampuan sosialisasi anak. Ketiga variabel tersebut berkaitan langsung dengan pola asuh, sedangkan banyak faktor lain yang juga berhubungan dengan pola asuh.

Pendidikan ibu berperan penting pada kemampuan kognitif ibu dan pola pengasuhan anak. Pola asuh anak akan berpengaruh pada perkembangan anak, yaitu kemampuan sosialisasi. ${ }^{13}$ Pekerjaan ibu akan berpengaruh bagi kuantitas dan kualitas pola asuh ibu sehingga akan berpengaruh bagi perkembangan anak. ${ }^{16}$ Status ekonomi, dengan keterlibatan orang tua dalam pengasuhan, juga berpengaruh dengan stres orang tua dan pola asuh. Pola asuh akan berakibat dengan kemampuan sosialisasi. ${ }^{15}$ Orang tua dapat lebih mencurahkan perhatian pada anaknya apabila ia tidak dibebani dengan masalah kebutuhan primer. ${ }^{6}$ Hasil penelitian menunjukkan bahwa terdapat hubungan antara pola asuh orang tua dengan kemampuan sosialisasi anak. Penelitian ini sesuai dengan beberapa penelitian yang melaporkan bahwa pola asuh berhubungan dengan kemampuan sosialisasi anak ${ }^{17-23}$

Interaksi antara orang tua dan anak merupakan dimensi penting dalam pola asuh, terdapat kehangatan dan strategi kontrol. Hubungan orang tua dan anak yang optimal erat kaitannya dengan kemampuan sosialisasi anak dan hubungan dengan teman sebaya. Komponen yang berperan penting, yaitu kehangatan, konflik, kontrol, dan monitoring. ${ }^{24}$ Orang tua merupakan pengasuh utama dan merupakan agen sosialisasi paling penting dalam hidup anak. Orang tua mengajarkan anak dengan memberitahu mereka apa yang boleh dan tidak boleh dilakukan dan memberi contoh bagi anak, kemudian anak mengimitasinya. ${ }^{25}$ Lingkungan rumah memiliki pengaruh yang besar pada perkem- bangan sosial. ${ }^{26} \mathrm{Ibu}$ dan keluarga memiliki pengaruh yang erat pada perkembangan anak. ${ }^{27}$ Perkembangan anak dipengaruhi oleh kesempatan, orang tua atau pengasuh yang responsif, bermain, komunikasi, dan aktivitas sosial. ${ }^{28}$

Pola asuh orang tua berkaitan dengan kemampuan sosialisasi anak. Pola asuh terdiri atas tiga jenis, yaitu otoritatif, otoriter, permisif. Pola asuh otoriter dan permisif dikelompokkan sebagai pola asuhnon otoritatif. Pola asuh otoriter merupakan gaya pengasuhan yang membatasi dan menghukum, yaitu orang tua mendesak anak untuk mengikuti arahan mereka dan menghormati pekerjaan dan upaya mereka. Pola asuh permisif merupakan gaya pengasuhan ketika orang tua sangat terlibat dengan anak, tetapi tidak terlalu menuntut atau mengontrol mereka. Orang tua dengan pola asuh permisif membiarkan anak melakukan apa yang anak inginkan. Pola asuh otoritatif merupakan pola asuh yang mendorong anak untuk mandiri, tetapi masih menerapkan batas dan kendali pada tindakan mereka. ${ }^{24}$

Pola asuh yang negatif berhubungan dengan perilaku anak yang sulit dan merasa tidak kompeten dalam membina relasi, kemampuan sosialisasi anak lambat, dan masalah internal meningkat. ${ }^{29}$ Orang tua yang otoriter lebih respek pada dirinya sendiri, tetapi kurang respek pada anak. ${ }^{25}$ Menurut Miller, ${ }^{30}$ konsekuensi dari pola asuh otoriter yaitu anak menjadi penakut, kurang kasih sayang dan kurang diterima, dan kehilangan kesempatan untuk dibimbing. Konsekuensi di masa depan bagi anak, yaitu keterampilan sosial dan kepercayaan diri yang kurang, pemarah, depresi, dan mudah cemas.

Perilaku ibu yang hangat berkaitan dengan kemampuan sosialisasi anak dalam membina hubungan interpersonal dengan teman sebaya dan lingkungan sosial. Pola asuh orang tua memiliki pengaruh yang besar pada perilaku anak. ${ }^{31}$ Orang tua yang hangat berhubungan positif dengan simpati, moral, dan perilaku sosial. Anak membutuhkan orang tua yang hangat walaupun ibu yang hangat lebih menentukan dibandingkan ayah yang hangat. Perkembangan prososial diidentifikasi oleh pola asuh dan karakteristik individu merupakan faktor penentu dari perilaku sosial. $^{32}$

Hasil dari penelitian kami dapat memberikan saran kepada orang tua untuk mengembangkan kemampuan sosialisasi anak. Salah satu caranya memberikan pola asuh otoritatif. Keterbatasan penelitian ini adalah 
desain penelitian cross sectional yang mungkin kurang sesuai untuk evaluasi variabel seperti pola asuh. Biodata dan data pola asuh didapat melalui pengisian kuesioner oleh orang tua subjek sehingga kemungkinan dapat terjadi bias karena subjek mengubah jawaban seperti yang kira-kira diinginkan oleh peneliti atau agar dianggap pola asuh dan biodatanya baik. Selain itu, juga dapat terjadi bias perhatian karena orang tua tahu sedang diteliti. Bias ini mungkin dapat diperkecil dengan penggunaan PSQ yang merupakan alat ukur yang valid dan reliabel. Disimpulkan bahwa pola asuh non otoritatif merupakan faktor yang ditemukan berhubungan dengan kurangnya kemampuan sosialisasi anak.

\section{Ucapan terima kasih}

Kepada Poltekkes Kemenkes Palembang atas semua kontribusi, A. Justi Lubis dan Dr. Hadyana Sukandar, M.Si atas bantuan. Guru PAUD serta seluruh responden penelitian yang membantu proses penelitian ini.

\section{Daftar pustaka}

1. Dirjen PAUD non formal dan informal. Petunjuk teknis penyelengaraan pos PAUD. Kemendiknas: Jakarta; 2011.

2. Henningham HB, Boo FL. Early childhood stimulation interventions in developing countries: a comprehensive literature review. IZA Discussion Paper No. 5282. Bonn: Forshunginstitut zur Zukunft der Arbeit (IZA);2010.

3. Zaiv Y. Social information processing patterns, social skills and school readiness in pre school children.J Exp Child Psychol.2013;114:306-20.

4. Arnold DH, Kupersmidt JB, Voegier-Lee ME, Marshall N. The Association between Preschool Children's Social Functioning and Their Emergent Academic Skills. Early Child Res Q 2012;27:376-86.

5. Smart D, Sanson A. The role of temperament and behavior. Fammatter 2001;59:10-5.

6. Gerungan WA. Psikologi sosial. Edisi ketiga. Bandung: Refika Aditama;2010.h.92.

7. Anme T, Shinohara R, Sugiyama Y, Tong L, Tanaka E, Watanabe T, dkk. Interaction rating scale (IRS) as an evidence based practical index of children's social skill and parenting. J Epidemiolog 2010;20(suppl2):S419-26.

8. Shaffer DR, Kipp K. Developmental Psychology childhood and adolescence. Edisi ke-8. Boston. Wadsworth Cengage
Learning;2010.

9. Setiadi EM, Kolip U. Pengantar sosiologi pemahaman fakta dan gejala permasalahan sosial: teori, aplikasi dan pemecahannya. Jakarta: Kencana;2011.

10. Pushpalata, Dhanda B, Singh CK. Family: a predictor a social competence of preschoolers. Stud Home Commsci 2009;3:63-6.

11. Onder A, Gulay H. Reliability and validity of parenting style \& dimension questionnaire. Procedia Soc Behav Sci 2009;1:508-14.

12. Pemerintah RI. Peraturan Pemerintah RI No. 32 tahun 2013 tentang perubahan atas Peraturan Pemerintah No. 19 Tahun 2005 tentang Standar Nasional Pendidikan: Jakarta; 2013.

13. Badan Pusat Statistik. Perkembangan upah minimum kota. BPS: Palembang;2013

14. Carneiro P, Meghir C, Parey M. Maternal education, home environment and the development of children and Adolescents. IZA Discussion Paper No. 3072. Germany;2007.

15. Gershoff ET, Raver CC, Aber JL, Lennon MC. Income is not enough: incorporating hardship into models of income associations with parenting and child development. Child Dev 2007;78:70-95.

16. Abedini Y. Zamani BE, Kheradmand A. Rajabizadeh G. Impacts of mothers; occupation status and parenting styles on levels of self control, addiction to computer games, and educational progress of adolescents. Addict Health 2012;4:102-10.

17. Mensah, Kuranchie MK, Alfred. Influence of parenting styles on the social development of children. AJIS 2013;2:123-9

18. Kol S. The effects of parenting styles on social skills of children aged 5-6. MOJES 2016;4:49-58.

19. Lavasani MG, Borhanzadeh S, Afzali L. Hejazi E. The relationship between perceived parenting styles, social support with psychological well-being. Procedia Soc Behav Sci 2011;15:1852-6.

20. Andriyana C. Hubungan pola asuh dan usia orang tua terhadap kemampuan sosialisasi anak usia 3-5 tahun di Paud Riyadhul Huda Bentarsari Kecamatan Salem Kabupaten Brebes Jawa Tengah (Skripsi). Purwokerto: Program Sarjana Keperawatan Universitas Muhammadiyah Purwokerto, 2012.

21. Xu C. Direct and indirect effects of parenting style with child temperrament, parent-child relationship and family functioning on child social competence in the Chinese cultur: testing the latent models (disertasi). Denton: Doctoral Program in Education of University of North Texas,2007.

22. Altay FB, Gure A. Relationship among the parenting styles and the social competence and prosocial behaviors of the children who are attending to state and private preschool. Edu Sci Theory and Practice 2012;12:2712-8. 
23. De Souza JF, Paul P. Perceived paternal parenting style and social competence. J Indian Acad Appl Psychol 2013;39:103-9.

24. Santrock JW. Perkembangan anak. Edisi ke-11 jilid 2. Jakarta: Erlangga;2007.h.167.

25. Latouf NCDS. Parenting styles affecting the behaviors of five years old (tesis). Pretoria: Master of Diaconology of University of South Africa,2008.

26. Huitt WG, Dawson C. Social development. Why it is important and how to impact it. Educational psychology interactive, Valdosta GA: Valdosta state university. April 2011. Diunduh 7 desember 2013. Didapat dari: http://www. edpsyinteractive.org/papers/socdev.pdf

27. Chowdhury S, Mitra M. Parenting Style and altruistic behavior of adolescents' life. J Res Hum Soc Sci 2015;3:20-4.

28. Malekpour M. Low birth weight infants and the importance of early intervention: enhancing mother-infant interactions a literature review. B. J Dev Disabil 2004;50:78-88.

29. Crnic KA, Gaze C, Hoffman C. Cumulative parenting stress across the preschool period: relations to maternal parenting and child behavior at age 5. Infant. Child Dev 2005;14:117-32.

30. Miller MJ. Authoritarian parenting. The center or christian counseling and relationship development LLC.2010. Diunduh 7 Desember 2013. Didapat dari: http://cccrd.publishpath.com/ Websites/cccrd/images/Authoritarian.pdf.

31. Drozdz E. Pokorski M. Parental attitudes and social competence in adolescents. J Physiol Pharmacol 2007;58:175-84.

32. Carlo G, Mestre MV, Samer P, Tur A, Armenta BE. The longitudinal relations among dimensions of parenting styles, sympathy, prosocial moral reasoning and prosocial behaviors. Int J Behav Dev 2010;35:116-24. 